\title{
Australian Journal of

\section{Evaluation of economic efficiency from smallholder cocoa investment in Indonesia: A case study in central Sulawesi province with tropical climate}

\author{
Effendy $^{1 *}$, Made Antara ${ }^{1}$, Rustam Abdul Rauf ${ }^{1}$, Dance Tangkesalu ${ }^{1}$, Christoporus ${ }^{1}$, M. Fardhal Pratama ${ }^{1}$, \\ Muhammad Basir-Cyioº ${ }^{2}$ Mahfudz ${ }^{2}$, Zainuddin², Muhardi
}

${ }^{1}$ Department of Agriculture Economics, Tadulako University, Palu Indonesia 94119

${ }^{2}$ Department of Agroecotechnology, Tadulako University, Palu, Indonesia 94119

\section{*Corresponding author: effendy_surentu@yahoo.com}

\begin{abstract}
This research aims to assess the financial feasibility of cocoa investment by smallholders in the province of Central Sulawesi Indonesia. Primary data were collected from 282 cocoa farmers in Sigi and Parigi Moutong Regency. Net Present Value (NPV) and Internal Rate of Return (IRR) were used to evaluate the financial feasibility of cocoa farming with the discount rate of $7 \%$ per year. The economic parameters were the price of input and output in 2018. The results showed that the NPV value of IDR 39,906,387 and IRR of 17.82 percent. This implied that smallholding of cocoa is financially feasible to be cultivated but with low profitability. It was due to the less intensive orchards cultivation and old age of cocoa plant. So, more intensive cultivation is required using the young plant and rejuvenation of the old cocoa plants. The government needs to promote cocoa cultivation technology that could improve the productivity of smallholder cocoa and the profitability of farming. So, the smallholding of cocoa in the province of central Sulawesi can become sustainable.
\end{abstract}

Keywords: Financial feasibility, net present value, internal rate of return, smallholder cocoa.

Abbreviations: b_the cumulative number of cash flows up to the $t_{i}$ year; $c$ _the number of cash flows in the $t_{i+1}$ year; $i$ years of the project; I_income; IRR_internal rate of return; IV_initial investment; NPV_net present value; PP_payment period; r_discount rate; TC_total cost; $\mathrm{t}_{\mathrm{i}}$ the last year where the number of net cash flows still cannot close Iv; TR_total revenue; Yi_total net cash inflows in the $\mathrm{n}^{\text {th }}$ year.

\section{Introduction}

Cocoa (Theobroma cacao) is a very important annual plant in Indonesia because it serves as a source of foreign exchange and jobs. Cocoa production depends on the plant life cycle, season, climate, soil fertility, water supply, pests and diseases attack (Mpika et al., 2009; Sabatier et al., 2013; Soh et al., 2013; Adu-Acheampong et al., 2014; Awudzi et al., 2016). Pest and disease attacks, old plant age, lack of resources and improper production mechanisms have resulted in decreased production and quality of cocoa beans in Indonesia (Neilson, 2008; Effendy, 2015; Effendy and Antara, 2015).

Cocoa production in Indonesia has a stagnant or decreasing trend (Effendy et al., 2013; Effendy, 2015; Effendy and Antara, 2015; Effendy, 2018). One of the possibilities that could change the current state is to apply new technologies such as somatic embryogenesis technology and side-grafting (DPDJP, 2009; Effendy et al., 2013; Claudia et al., 2016). The cause of this negative state is the high investment cost on the establishment of the orchards, regardless limitations in of biotechnological methods as well (Sojková and Adamičková, 2011; Patil and Poddar, 2016).

The problem of cocoa bean production has not been resolved completely. This was evidenced by the decrease in cocoa beans production exports, the decrease of the orchards area and the yield per hectare (Effendy, 2015; Effendy and Antara, 2015; Effendy, 2018). Farming companies were forced to follow changes in the international market, so the new investment decision became a solution.

Based on indicators such as operating costs, it has been found that labor costs represented 46.90 percent of total variable costs (Effendy, 2015). These costs could be reduced by improving labor productivity and introducing resistant varieties against various diseases and pests. Reducing operating costs would improve cost efficiency so that they would improve product competitiveness (Patil and Poddar, 2016; Effendy, 2018).

Economic efficiency of cocoa farming became the strategic task of farmers. The decrease in cocoa farming production costs caused competition amongst farmers in Indonesia. Therefore, the task of farmers was to create the new orchards with higher production per unit. Improvements in the efficiency of agricultural economy were highly dependent on the obedience of farmers in reducing nonproductive expenditures (Sojková and Adamičková, 2011; Zereyesus and Dalton, 2017). To fulfill all these tasks, it is necessary to analyze systematically all the costs of production, revenue, and income in cocoa farming. 
The greatest influence on economic efficiency was the result. The yield of cocoa can directly affect the income earned from the sale. The high cost of production can also affect the yield of Cocoa bean. So, it enabled farmers to choose a relatively complex and varied approach to plan cocoa orchard investment projects with the approach of Net Present Value and Internal Rate of Return (Armsworth et al., 2011; Li et al., 2012; Svennebring and Wikberg, 2013; BodeGreuel and Nickisch, 2014; Matos et al., 2015; Patil and Poddar, 2016; Zereyesus and Dalton, 2017).

\section{Results and Discussion}

\section{Age and productivity of cocoa plants}

The relations between age and productivity of cocoa plants are listed in Table 1.

Table 1. shows that higher age of cocoa plants can decrease productivity. This was supported by Effendy (2015). According to Yuono (2018) cocoa plants began to produce fruit from 2.5 to 3 years after planting. The optimal productivity was achieved at the age of 7 to 11 years, about 1.8 tonnes of dried cocoa beans per hectare per year. Table 1 also shows that $38 \%$ of cocoa plants were older than 18 years. This indicates that the productivity of cocoa plants started to decrease. Decreasing productivity could reduce cocoa farming income so that it would affect the level of profitability (Fig 1).

Fig 1 also shows that older cocoa plant, produce less profitability. This indicates that the old cocoa orchards needed to be rejuvenated so that the level of profitability remaines high. Rejuvenation of old cocoa plants was strongly supported by the government through side-grafting technology (Effendy et al., 2013).

\section{Cultivation costs and profitability of cocoa farming}

The cultivation costs in this research were identical to variable costs or production costs. The relations between cultivation costs and cocoa farming profitability are shown in Fig 2.

Fig 2 shows that the use of cultivation costs in the smallholder cocoa farming is still low so that there is a tendency to increase profitability. This happened because of the cultivation costs including the cost of fertilizers, pesticides, and labor (production inputs). The use of fertilizer and labor could increase the production and quality of cocoa (Effendy, 2015; Effendy and Antara, 2015; Effendy, 2018).

Relations of the total costs, revenue, and income of cocoa farming

Figure 3 shows the total costs, revenue, and income of cocoa farming in the research area. The factors vary based on plant age. In general, the operating cost of cocoa farming was rather constant, but it was lower at the age of 29 years old plantations. The income of cocoa farming was also variable. It decreased with the increased age of the plant (Effendy, 2015). The revenue of cocoa farming was also decreased. The revenue of cocoa farming decreased due to the reduction in production (Table 1 ).
Table 1 . shows that the decrease in production is strongly related to cocoa plant age. The older the cocoa plant, the lower the farming yield (Effendy, 2015). The development of income and cost, as well as investment costs is reflected in the cash flows (Figure 4). The benefits of the cocoa orchards were achieved in the fourth year.

On average, the benefits of the cocoa orchards are expected from years 4 to 15 . In the $21^{\text {st }}$ year, the benefits of the orchards are predicted to decrease. This is related with decreased yields of the orchards (Sojková and Adamičková, 2011; Patil and Poddar, 2016).

\section{Benefits of cocoa orchards}

The benefits of the cocoa orchards were assessed by criteria of net present value (NPV), internal rate of return (IRR), and payment period (PP). PP was an additional criterion because it does not consider the time-value of money (Sojková and Adamičková, 2011). Net present value (NPV), internal rate of return (IRR), and Payment period (PP) are shown in Table 2.

Table 2 shows a positive NPV, where IRR $=17.82$ percent $>$ interest credit of smallholder (ICS) $=7$ percent (Pebrianto, 2018), and PP $=8$ years. This implies that the project investment of cocoa farming is considered financially feasible, but it has low-profitability level (Sojková and Adamičková, 2011). If the discount rate were $>7$ percent, NPV would decrease. In that case, cocoa farming investment would become not ineffective because of the lower profitability level. Under unfavorable low-yield conditions, operating costs were increased because the plants were old and pests could attack the plants easily (Neilson, 2008; Effendy et al., 2013; Effendy and Antara, 2015). In that case, NPV was dropped below the zero (Figure 5).

Figure 5 shows that NPV development was dependent on the change of discount rate (Matos et al., 2015; Patil and Poddar, 2016). The development of NPV was not linear. It described the sensitivity of NPV in the certain alternative. The NPV was affected by the discount rate (Bode-Greuel and Nickisch, 2014). Its increase affected the investment of the cocoa farming project. Based on the criteria of NPV and IRR on cocoa farming investment in our research area, the cocoa cultivation was economically less efficient, so it is necessary to rejuvenate the old cocoa plantations and more intensive cultivation of younger plants.

\section{Materials and Methods}

\section{Research areas and plant material}

The Sigi and Parigi Moutong Regency regions were randomly selected as sample regions for this research. Berdikari and Rahmat Village represented Sigi Regency, Sidole and Tanampedagi Village represented Parigi Moutong Regency. The four selected villages are cocoa producing villages in Central Sulawesi Province. The number of samples used in this research was 282 cocoa farming. Characteristics of cocoa farming are listed in Table 3.

Table 3 shows the average farmers, cultivating cocoa, less than 2 ha. This indicates that cocoa farming was managed on a small scale. The average of cocoa plants age was 18 years 
Table 1. Relations between age and productivity of cocoa plants.

\begin{tabular}{|c|c|c|c|c|}
\hline Number & Plants age (Year) & $\begin{array}{l}\text { Number of } \\
\text { household }\end{array}$ & Percentage (\%) & Cocoa productivity (tonnes. ha $^{-1}$ ) \\
\hline 1 & 7 & 3 & 1.06 & $1,072.78$ \\
\hline 2 & 8 & 7 & 2.48 & $1,148.10$ \\
\hline 3 & 9 & 4 & 1.42 & 877.08 \\
\hline 4 & 10 & 8 & 2.84 & 917.53 \\
\hline 5 & 11 & 5 & 1.77 & 970.00 \\
\hline 6 & 12 & 15 & 5.32 & 947.17 \\
\hline 7 & 13 & 16 & 5.67 & 922.81 \\
\hline 8 & 14 & 17 & 6.03 & 843.41 \\
\hline 9 & 15 & 27 & 9.57 & 736.27 \\
\hline 10 & 16 & 16 & 5.67 & 664.34 \\
\hline 11 & 17 & 28 & 9.93 & 662.33 \\
\hline 12 & 18 & 30 & 10.64 & 725.53 \\
\hline 13 & 19 & 25 & 8.87 & 685.00 \\
\hline 14 & 20 & 10 & 3.55 & 722.00 \\
\hline 15 & 21 & 15 & 5.32 & 660.78 \\
\hline 16 & 22 & 5 & 1.77 & 617.00 \\
\hline 17 & 23 & 6 & 2.13 & 576.94 \\
\hline 18 & 24 & 6 & 2.13 & 420.83 \\
\hline 19 & 25 & 12 & 4.26 & 414.03 \\
\hline 20 & 26 & 5 & 1.77 & 428.67 \\
\hline 21 & 27 & 8 & 2.84 & 327.50 \\
\hline 22 & 28 & 10 & 3.55 & 367.00 \\
\hline 23 & 29 & 4 & 1.42 & 287.50 \\
\hline Total & & 282 & 100.00 & \\
\hline Average & 18 & & & 695.42 \\
\hline
\end{tabular}

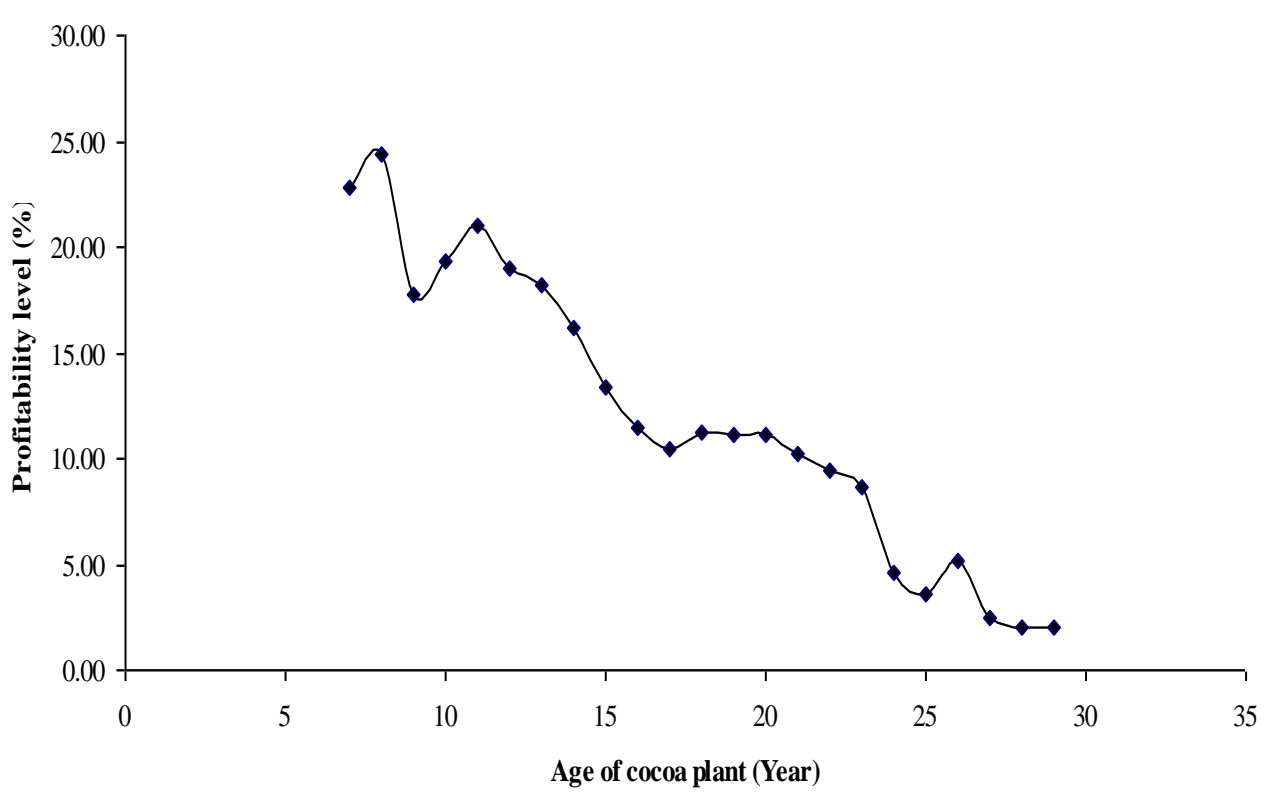

Fig 1. Relations between the cocoa plants age and profitability.

Table 2. Value of NPV, IRR, and PP smallholder cocoa.

\begin{tabular}{llll}
\hline & & \\
\hline NPV (IDR) & IRR (\%) & PP (Year) \\
\hline Value & $39,906,387$ & 17.82 & 8 \\
\hline
\end{tabular}

Note: assuming investment from the source itself, NPV = net present value, IRR = internal rate of return, $\mathrm{PP}=$ payment period. 


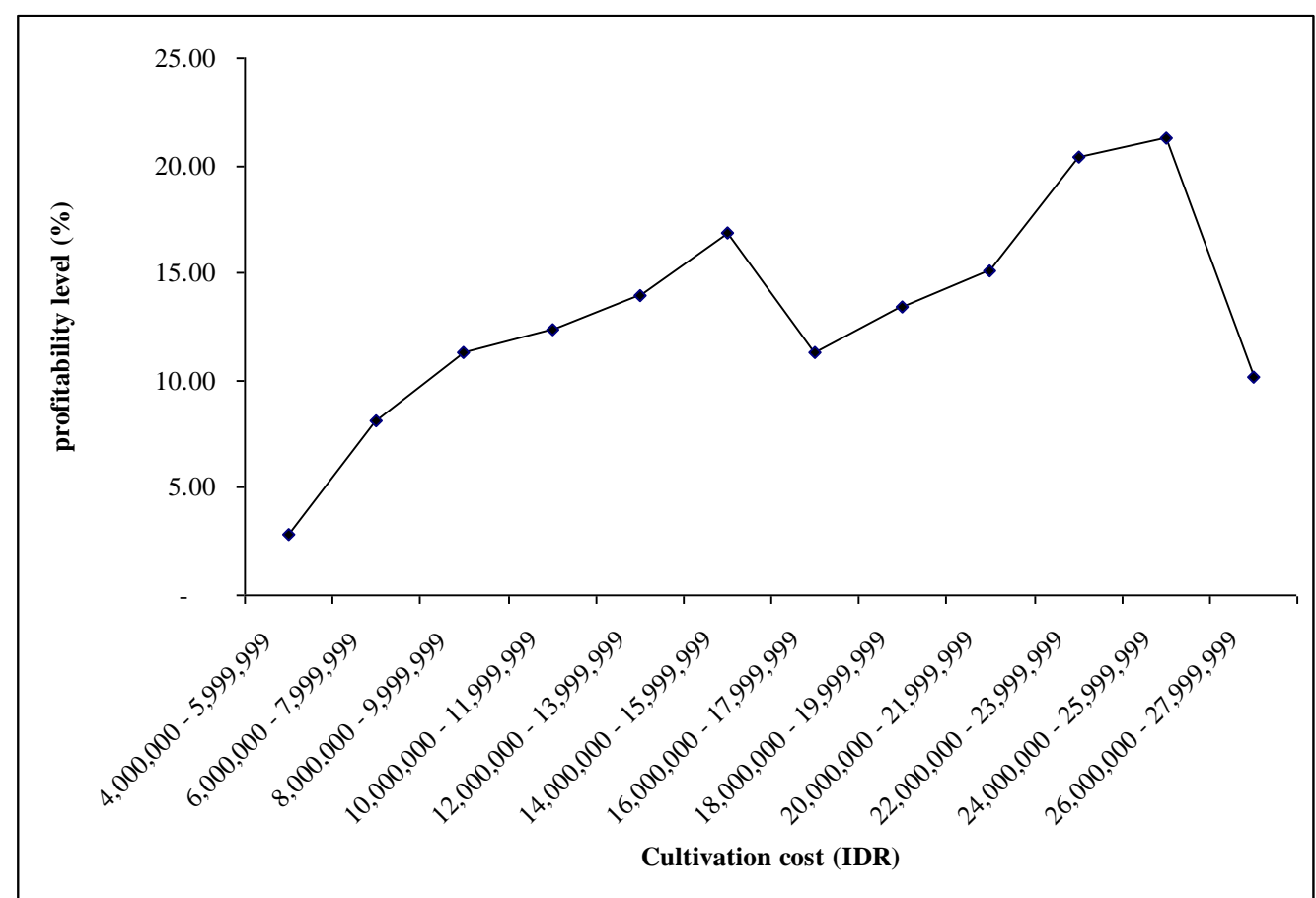

Fig 2. The relations between cultivation costs and the profitability of cocoa farming. Note: IDR 13,829=1 USD as on April 2018 .

Table 3. Characteristics of cocoa farming.

\begin{tabular}{lccc}
\hline Variable & Units & Mean & Std. Deviation \\
\hline Land & ha & 1.60 & 0.58 \\
Plant age & Year & 18 & 5.11 \\
Total cost (TC) & IDR/ha & $10,404,084.93$ & $2,437,501.65$ \\
Total revenue (TR) & IDR/ha & $22,577,445.19$ & $7,048,685.48$ \\
Income (I) & IDR/ha & $12,173,360.26$ & $6,560,890.79$ \\
investment (IV) & IDR/ha & $101,744,504.18$ & $649,221.92$ \\
profitability & $\%$ & 11.99 & 6.49 \\
\hline
\end{tabular}

Note: IDR 13,829 = 1 USD as on April 2018.

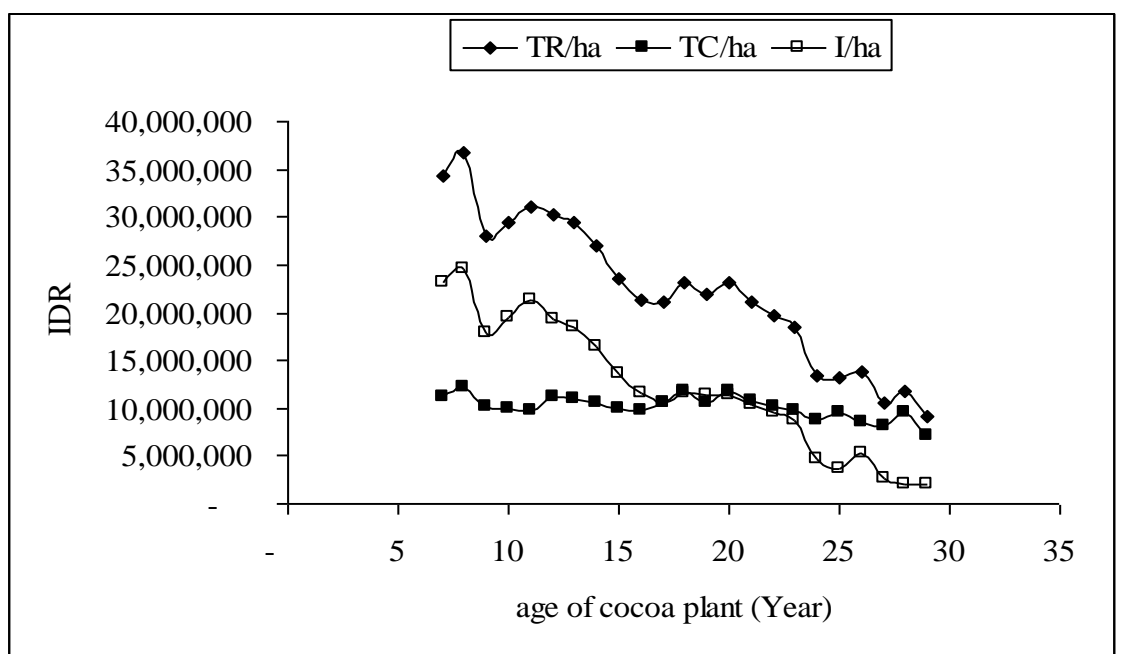

Fig 3. The development of costs, revenue, and income of cocoa farming. Note: IDR 13,829=1 USD as on April 2018. 


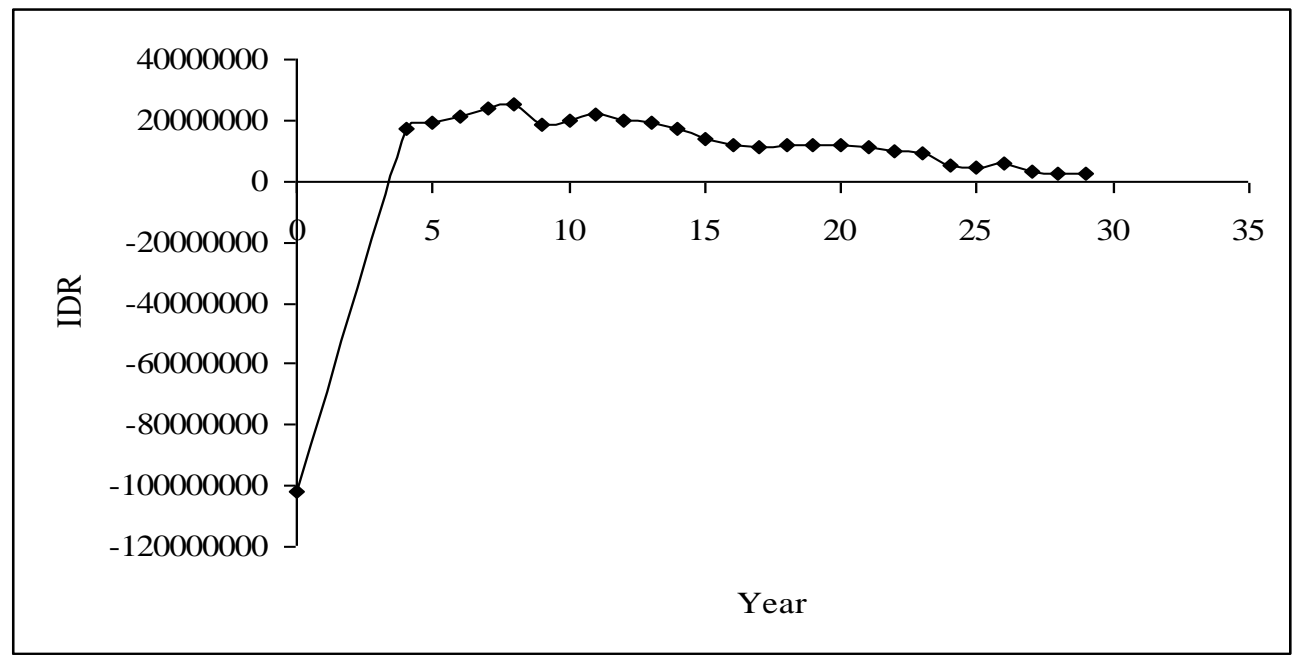

Fig 4. The development of cash flows from cocoa orchards investment. Note: IDR 13,829=1 USD as on April 2018.

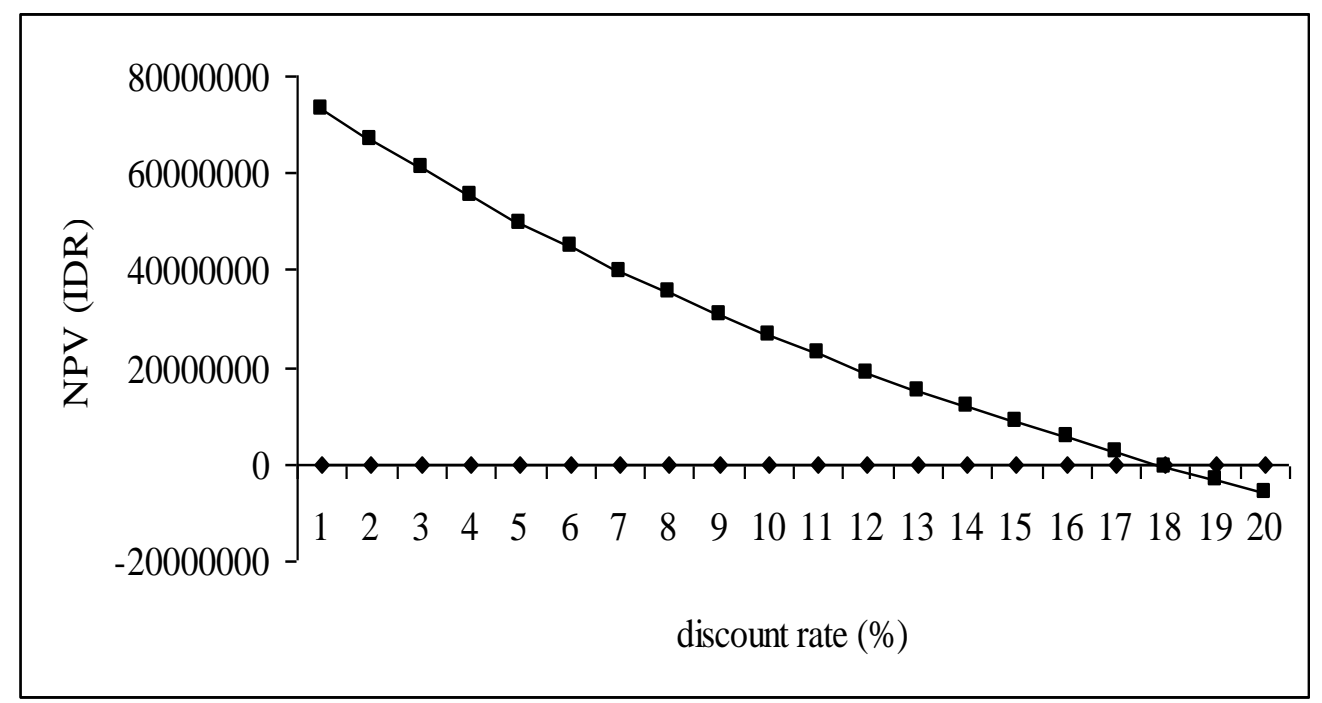

Fig 5. The development of cocoa farming NPV. Note: IDR 13,829=1 USD as on April 2018.

which indicated that cocoa production has begun to decrease (Effendy, 2015; Yuono, 2018). The average profitability of cocoa farming was $11.99 \%$. This showed that farmers were rather slow in returning investment.

\section{Financial and economic methods}

Net Present Value (NPV), Internal Rate of Return (IRR), Payback Period (PP), and Profitability Ratio were used to evaluate the economic efficiency of cocoa farming in Central Sulawesi Province, Indonesia. NPV is the comparison between net cash PV with investment PV during investment age, calculated by the equation:

$$
N P V=\sum_{i=1}^{n} Y_{i}(1+r)^{-i}-I v
$$

Where,

$\mathrm{Yi}=$ Total net cash inflows in the $\mathrm{n}^{\text {th }}$ year

$r=$ discount rate

Iv = Initial investment $i=$ years of the project: $1,2, \ldots n$.

If the NPV is a positive value, then it is worth it to continue the project.

IRR is an indicator of the efficiency level from an investment. IRR is calculated by the equation:

$$
N P V=\sum_{i=1}^{n} Y_{i}(1+I R R)^{-i}-I v=0
$$

If IRR > $r$ then work is considered to be feasible.

The PP is a necessary period to be able to close again investment expenditures by using net cash flows. PP is calculated by the equation:

$P P=\left(t_{i}+\frac{I v-b}{c}\right) \cdot 1$ Year

$t_{i}=$ The last year where the number of net cash flows still cannot close Iv.

$b=$ The cumulative number of cash flows up to the $t_{i}$ year $c=$ The number of cash flows in the $t_{i+1}$ year 
Profitability Ratio is a ratio to determine the ability of a company to obtain income from revenue related to sales, assets, and equity based on certain measurement bases. The measurement of profitability ratio in this research used a return on equity ratio (ROE). ROE is a profitability ratio to assess the company's ability to generate incomes from the investment of the company's shareholders expressed in percentages (Equation 4).

$\mathrm{ROE}=$ Income after tax: Equity of shareholders

Other output information used net cash flows from all investment planning periods of cocoa farming. The economic parameters of the system were based on the price of input and output in 2018.

\section{Conclusion}

The results showed that the operating cost of cocoa farming was rather constant, which implies that the input is not adapted with the needs of cocoa plants. It was possible that cocoa farmers were underfunded, so that financial support with lower interest rates is required for sustainability of cocoa farming in the research area. Based on the criteria of NPV and IRR on cocoa farming investment in the research area, the cocoa cultivation is financially feasible, but low profitability level is expected aminly due to the old age of planations. Therefore, it is necessary to rejuvenate the old cocoa plantations and perform more intensive maintenance of the young plants. The government can promote cocoa cultivation technology that improves the productivity of the smallholder cocoa so it could improve the profitability of farming.

\section{Acknowledgments}

The authors would like to thank the Directorate of Research and Community Service, Directorate General of Strengthening Research and Development of Research Ministry, Technology and Higher Education of the Republic of Indonesia for providing fund support for this research.

\section{References}

Adu-Acheampong R, Jiggins J, van Huis A, Cudjoe AR, Johnson AR, Sakyi-Dawson O, Ofori-Frimpong K, OseiFosu P, Tei-Quartey E, ... et al., Quarshie ETN (2014) The cocoa mirid (hemiptera: miridae) problem: evidence to support new recommendations on the timing of insecticide application on cocoa in Ghana. Int J of Trop Ins Sci. 34(1): 58-71.

Armsworth PP, Block BA, Eagle J, Roughgarden JE (2011) The role of discounting and dynamics in determining the economic efficiency of time-area closures for managing fishery bycatch. Theor Ecol. 4: 513-526.

Awudzi GK, Asamoah M, Owusu-Ansah F, Hadley P, Hatcher PE, Daymond AJ (2016) Knowledge and perception of Ghanaian cocoa farmers on mirid control and their willingness to use forecasting systems. Int J of Trop Ins Sci. 36: 22-31.

Bode-Greuel KM, Nickisch K (2014) Deciding between biobetter versus biosimilar development options based on net present value calculations. J of Comm Bio. 20(2): 21-31.
Claudia G, Fabio C, Seth F, Alex-Alan A, Marcio C, Carlos MJ, Ray S, Jean-Philippe M (2016) Optimization of somatic embryogenesis procedure for commercial clones of Theobroma cacao L. Afr J of Bio. 15: 19361951.

DPDJP (2009) Buku panduan teknis budidaya tanaman kakao (Theobroma cacao L.). Gerakan peningkatan produksi dan mutu kakao nasional (Gernas), Departemen Pertanian Direktorat Jenderal Perkebunan (DPDJP), Jakarta.

Effendy (2015) Increasing of cocoa farmers household income with two stage least squares method. Mod App Sci. 9(6): $120-127$.

Effendy (2018) Factors affecting variation of total factor productivity in cocoa farming in the Central Sulawesi, Indonesia. Aust J Crop Sci. 12(04): 655-660.

Effendy, Antara M (2015) Effect of input production against quality of cocoa beans. Ame J of App Sci. 12(10): 709-713.

Effendy, Hanani N, Setiawan B, Muhaimin AW (2013) Effect characteristics of farmers on the level of technology adoption side-grafting in cocoa farming at Sigi Regency-Indonesia. J of Agri Sci. 5 (12): 72-77.

Li K, Naganawa S, Wang K, Li P, Kato K, Li X, Zhang J, Yamauchi K (2012) Study of the cost-benefit analysis of electronic medical record systems in general hospital in China. J Med Syst. 36: 3283-3291.

Matos C, Bentes I, Santos C, Imteaz M, Pereira S (2015) Economic analysis of a rainwater harvesting system in a commercial building. Water Res Manage. 29: 39713986.

Mpika J, Kébé IB, Issali AE, N'Guessan FK, Druzhinina S, Komon-Zélazowska M, Kubicek CP, Aké S (2009) Antagonist potential of Trichoderma indigenous isolates for biological control of Phytophthora palmivora the causative agent of black pod disease on cocoa (Theobroma cacao L.) in Côte d'Ivoire. Afr J of Bio. 8(20): 5280-5293.

Neilson J (2008) Program gerakan nasional percepatan revitalisasi kakao nasional (GERNAS). Masukan strategis dari Forum Kemitraan Kakao Berkelanjutan (Cocoa Sustainability Partnership), ACIAR. http://www.google.co.id/\#bav=on.2,or.r_qf.\&fp=442bd ad5c6096e1d\&q=Program+Gerakan+Nasional+Percepat an+Revitalisasi+Kakao+Nasional+\%28GERNAS\%29. (accessed February 2016).

Patil BO, Poddar RS (2016) Financial feasibility of drip irrigation system in grape cultivation. Int J of Agri, Env and Bio. 9(4): 617-624.

Pebrianto F (2018) Bunga KUR turun jadi 7 persen, efektif per 1 Januari 2018. https://bisnis.tempo.co/read/1055468/bunga-kurturun-jadi-7-persen-efektif-per-1-januari-2018 (accessed April 2018)

Sabatier R, Wiegand K, Meyer K (2013) Production and robustness of a cacao agroecosystem: effects of two contrasting types of management strategies. PLOS ONE 8(12): e80352.

Soh PT, Ndoumbè-Nkeng $M$, Sache I, Nguema EPN, Gwet H, Chadoeuf J (2013) Development stage-dependent 
susceptibility of cocoa fruit to pod rot caused by Phytophthora megakarya. Eur J Plant Pathol. 135:363370.

Sojková Z, Adamičková I (2011) Evaluation of economic efficiency of the orchards investment project with respect to the risk. Agric. Econ. - Czech. 57(12): 600608.
Svennebring AM, Wikberg JE (2013) Net present value approaches for drug discovery. SpringerPlus, 2, 140. http://www.springerplus.com/content/2/1/140

Yuono T (2018) Teknik panen buah kakao yang baik. Alamtani. https://alamtani.com/panen-buah-kakao/ (accessed October 2018).

Zereyesus YA, Dalton TJ (2017) Rates of return to sorghum and millet research investments: A metaanalysis. PLoS ONE. 12(7): e0180414. 